\title{
UJI BEBERAPA KONSENTRASI EKSTRAK TEPUNG DAUN BINTARO (Cerbera manghas L.) TERHADAP HAMA PENGGEREK TONGKOL JAGUNG MANIS (Helicoverpa armigera Hubner)
}

\section{Test the Some Concentrations of Bintaro Leaf Flour Extract (Cerbera manghas L.) against Sweet Corn Cobs Borer (Helicoverpa armigera Hubner)}

\author{
Muslihat $^{1)}$ dan Desita Salbiah ${ }^{2)}$ \\ ${ }^{1)}$ Mahasiswa Jurusan Agroteknologi, Fakultas Pertanian, Universitas Riau \\ ${ }^{2)}$ Dosen jurusan Agroteknologi, Fakultas Pertanian, Universitas Riau \\ Email: Muslihatmt@gmail.com/ 082389739653 \\ [Diterima: Desember 2019; Disetujui: April 2020]
}

\begin{abstract}
The main pest that often attacks sweet corn crops is Helicoverpa armigera Hubner and causes damage. Pest control can be done using botanical insecticide bintaro plants (Cerbera manghas L.) The aim of this research was to get an effective concentration of bintaro leaf flour extract against of Helicoverpa armigera Hubner. The research was carried out experimentally at the Laboratory of Plant Pests, Agricultural Faculty, University of Riau, by using a completely randomized design (CRD) with four treatments and five replications. The treatments consisted of the several levels of concentration of bintaro leaf flour extract, $40 \mathrm{~g} . \mathrm{l}^{-1}$ water, $60 \mathrm{~g} . \mathrm{l}^{-1}$ water, $80 \mathrm{gg} . \mathrm{l}^{-1}$ water and $100 \mathrm{~g} . \mathrm{l}^{-1}$ water. The parameters observed were initial time of death (hours), lethal time 50 (hours), and total mortality (\%). The results showed that bintaro leaf extract with a concentration of 80 g. $1^{-1}$ water was an effective concentration to control $H$. armigera pests which could cause a total mortality of $82 \%$ with an initial death of 15,4 hours after application and lethal time $50\left(\mathrm{LT}_{50}\right) 57,4$ hours after application.
\end{abstract}

Keywords: Helicoverpa armigera Hubner, Bintaro plants, Botanical insecticide

\section{ABSTRAK}

Hama utama yang sering meyerang pertanaman jagung manis yang menyebabkan kerusakan adalah Helicoverpa armigera Hubner. Pengendalian hama dapat dilakukan dengan menggunakan pestisida nabati tanaman bintaro (Cerbera manghas L.). Penelitian bertujuan untuk mendapatkan konsentrasi ekstrak tepung daun bintaro yang efektif terhadap mortalitas hama Helicoverpa armigera Hubner. Penelitian dilaksanakan secara eksperimen di Laboratorium Hama Tumbuhan, Fakultas Pertanian, Universitas Riau, menggunakan rancangan acak lengkap (RAL) dengan empat perlakuan dan lima ulangan. Perlakuan yang diberikan adalah beberapa tingkat konsentrasi ekstrak tepung daun bintaro yaitu 40 g. $1^{-1}$ air, $60 \mathrm{~g} .1^{-1}$ air, $80 \mathrm{~g} .1^{-1}$ air dan $100 \mathrm{~g} .1^{-1}$ air. Parameter yang diamati adalah waktu awal kematian (jam), lethal time (jam) dan mortalitas total (\%). Hasil penelitian menunjukkan bahwa ekstrak tepung daun bintaro dengan konsentrasi 80 g..$^{-1}$ air merupakan konsentrasi yang efektif untuk mengendalikan hama $H$. armigera dimana dapat menyebabkan mortalitas total sebesar $82 \%$ dengan awal kematian 15,4 jam setelah aplikasi dan lethal time $50\left(\mathrm{LT}_{50}\right)$ 57,4 jam setelah aplikasi.

Kata kunci: Helicoverpa armigera Hubner, tanaman bintaro. Insektisida botani.

\section{PENDAHULUAN}

Hama utama yang sering meyerang pertanaman jagung manis adalah hama penggerek tongkol (Helicoverpa armigera). Menurut Sarwono et al. (2003) gejala serangan larva $H$. armigera dimulai pada saat pembentukan kuncup bunga, bunga dan buah muda. Larva masuk ke dalam buah muda, menggerek tongkol dan memakan biji jagung. Kerusakan akibat serangan hama ini dapat mengakibatkan hasil produksi tanaman jagung manis menurun. Serangan larva $H$. armigera biasanya terjadi pada musim kemarau dan menyebabkan penurunan hasil produksi jagung hingga $80 \%$ (Zulaiha et al., 2012)

Upaya pengendalian hama $H$. armigera yang dilakukan petani hingga saat ini masih menggunakan insektisida kimia sintetik dengan frekuensi dan dosis melebihi yang direkomendasikan. Penggunaan insektisida 
sintetik yang terus menerus dan tidak bijaksana dapat menimbulkan dampak negatif terhadap hama dan lingkungan (Direktorat Jendral Tanaman Pangan, 1989). Alternatif lebih aman yaitu penggunaan insektisida nabati yang aman bagi lingkungan. Tumbuhan insektisida nabati yang aman bagi lingkungan adalah tanaman bintaro.

Penelitian tentang penggunaan ekstrak tepung daun bintaro untuk mengendalikan hama larva $H$. armigera sebelumnya telah dilakukan. Putri (2018) melaporkan bahwa pemberian ekstrak tepung daun bintaro dengan konsentrasi tertinggi yaitu 25 g. $\mathrm{l}^{-1}$ air hanya mampu membunuh serangga uji larva $H$. armigera sebesar 52,5\%. Namun, konsentrasi tersebut belum mencapai batas maksimal yang direkomendasikan yaitu $10 \%$ dengan pelarut air sehingga masih dapat dilakukan peningkatanan konsentrasi yang lebih tinggi yaitu dengan konsentrasi maksimal $100 \mathrm{g.l}^{-1}$ air. Hal ini sesuai dengan pendapat Dadang dan Prijono (2008) bahwa insektisida dikatakan efektif apabila mampu mematikan serangga hama lebih dari $80 \%$ dengan pelarut organik pada konsentrasi yang tidak melebihi dari $1 \%$ dan untuk ekstrak air tidak lebih dari $10 \%$.

Berdasarkan uraian tersebut maka penulis telah melaksanakan penelitian dengan judul "Uji Beberapa Konsentrasi Ekstrak Tepung Daun Bintaro (Cerbera manghas L.) terhadap Hama Penggerek Tongkol Jagung manis (Helicoverpa armigera Hubner). Penelitian bertujuan untuk mendapatkan konsentrasi ekstrak tepung daun bintaro yang efektif terhadap mortalitas hama penggerek tongkol jagung manis (Helicoverpa armigera Hubner).

\section{METODOLOGI}

Penelitian telah dilaksanakan di Laboratorium Hama Tumbuhan Fakultas Pertanian Universitas Riau Kampus Bina Widya km 12,5 Pekanbaru. Penelitian dilaksanakan selama 3 (tiga) bulan dari bulan Juli sampai September 2019.

Bahan yang digunakan dalam penelitian ini adalah tongkol jagung manis, larva penggerek tongkol jagung (Helicoverpa armigera) instar 3, daun bintaro (Cerbera manghas L.), serbuk gergaji, madu, kapas, tisu, aquades steril, dan sabun krim.
Alat yang digunakan dalam penelitian ini adalah stoples berdiameter $24 \mathrm{~cm}$ dan tinggi $27 \mathrm{~cm}$, wadah plastik berdiameter $2,5 \mathrm{~cm}$ dan tinggi $4 \mathrm{~cm}$, wadah plastik berdiameter $5,5 \mathrm{~cm}$ dan tinggi $12 \mathrm{~cm}$, wadah plastik berdiameter $15 \mathrm{~cm}$ dan tinggi $20 \mathrm{~cm}$, gunting, blender, timbangan analitik, kain kassa, ayakan, saringan, batang pengaduk, hand sprayer ukuran $500 \mathrm{ml}$, termohygrometer, kertas label, kamera, dan alat tulis

Penelitian dilaksanakan secara eksperimen menggunakan rancangan acak lengkap (RAL) dengan empat perlakuan dan lima ulangan sehingga diperoleh 20 unit percobaan. Tiap unit percobaan diinfestasikan 10 ekor larva $H$. armigera instar 3. Perlakuan yang diberikan adalah beberapa tingkat konsentrasi ekstrak tepung daun bintaro (B),

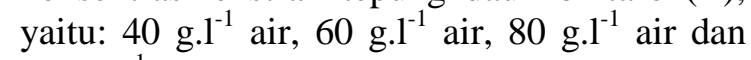
100 g. $1^{-1}$ air.

Parameter pengamatan terdiri dari awal kematian (jam), lethal time 50 (jam) dan mortalitas total (\%).Data yang diperoleh dari hasil penelitian dianalisis secara statistik dan diuji lanjut dengan dengan menggunakan uji Beda Nyata Jujur (BNJ) pada taraf 5\%.

\section{HASIL DAN PEMBAHASAN}

Hasil pengamatan awal kematian larva $H$. armigera setelah dianalisis dengan menggunakan sidik ragam menunjukan bahwa perlakuan peningkatan beberapa konsentrasi ekstrak tepung daun bintaro memberikan pengaruh nyata terhadap waktu awal kematian larva $H$. armigera pada setiap perlakuan. Hasil uji lanjut BNJ pada taraf 5\% dapat dilihat pada Tabel 1.

Tabel 1 menunjukkan bahwa pemberian ekstrak tepung daun bintaro dengan konsentrasi tertinggi 100 g. $l^{-1}$ air menunjukkan waktu awal kematian tercepat yaitu 14,0 jam setelah aplikasi. Konsentrasi ini berbeda tidak nyata dengan konsentrasi ekstrak tepung daun bintaro 60 g. $1^{-1}$ air dan 80 g..$^{-1}$ air yaitu masingmasing 21,8 jam dan 15,4 jam dan berbeda nyata dengan konsentrasi ekstrak tepung daun bintaro 40 g. $1^{-1}$ air yaitu 35,4 jam setelah aplikasi. Peningkatan beberapa ekstrak tepung daun bintaro mampu mempercepat waktu awal kematikan $H$. armigera. Hal ini diduga bahwa semakin tinggi konsentrasi yang digunakan maka jumlah bahan aktif yang terkandung dalam ekstrak tepung daun bintaro akan semakin meningkat dan akan mempercepat 
waktu awal kematian larva $H$. armigera. Yunita et al. (2009) menyatakan bahwa semakin tinggi konsentrasi senyawa insektisida yang digunakan maka tingkat kematian serangga uji semakin tinggi pula.

Berdasarkan hasil penelitian Putri (2018) melaporkan bahwa pemberian ekstrak tepung daun bintaro dengan konsentrasi tertinggi 25 g. $1^{-1}$ air waktu awal kematian larva $H$. armigera yaitu 26,7 jam sedangkan hasil penelitian yang telah dilakukan dengan konsentrasi yang lebih tinggi yaitu 40 g..$^{-1}$ air menyebabkan kematian larva $H$. armigera yang lebih lama yaitu 35,4 jam. Hal ini diduga karena umur larva $H$. armigera yang digunakan berbeda serta larva $H$. armigera yang digunakan juga diperoleh dari tempat yang berbeda sehingga larva memberikan respon yang berbeda terhadap waktu awal kematian. Hal ini sesuai dengan pendapat Syahputra dan Endarto (2012) yang menyatakan bahwa berbagai faktor dapat mempengaruhi suatu insektisida dalam menyebabkan kematian serangga sasaran, diantaranya jenis insektisida, konsentrasi dan cara aplikasi insektisida, jenis serangga, fase perkembangan dan umur serangga serta faktor lingkungan. Namun, peningkatan konsentrasi ekstrak tepung daun bintaro menjadi $60 \mathrm{~g} . \mathrm{l}^{-1}$ air waktu awal kematian larva $H$. armigera menjadi lebih cepat yaitu 21,8 jam, begitu juga dengan peningkatan konsentrasi ekstrak tepung daun bintaro menjadi 80 g..$^{-1}$ air dan 100 g. $1^{-1}$ air yaitu 15,4 jam dan 14,0 jam.

Tabel 1. Rata-rata awal kematian larva H. armigera dengan beberapa konsentrasi ekstrak tepung daun bintaro

\begin{tabular}{cc}
\hline Konsentrasi ekstrak tepung daun bintaro (g. ${ }^{-1}$ air $)$ & Waktu awal kematian (jam) \\
\hline 40 & $35,4 \mathrm{a}$ \\
60 & $21,8 \mathrm{ab}$ \\
80 & $15,4 \mathrm{~b}$ \\
100 & $14,0 \mathrm{~b}$ \\
\hline
\end{tabular}

Angka-angka pada lajur yang diikuti oleh huruf kecil yang tidak sama berbeda nyata menurut uji BNJ pada taraf $5 \%$ setelah ditransformasi dengan formula $\sqrt{\mathrm{y}}$

Hal ini menunjukkan bahwa peningkatan konsentrasi ekstrak tepung daun bintaro dapat mempercepat waktu awal kematian larva $H$. armigera. Hasil penelitian Dewi (2017) menunjukkan bahwa peningkatan konsentrasi ekstrak tepung biji pinang dari 50 g..$^{-1}$ air menjadi 60 g. $1^{-1}$ air mampu mempercepat waktu awal kematian larva $H$. armigera selama 7,25 jam setelah aplikasi. Hal ini sesuai dengan pernyataan Mulyana (2002) menyatakan bahwa pemberian konsentrasi yang tinggi menyebabkan serangga cepat mengalami kematian, hal ini disebabkan banyaknya bahan aktif yang masuk ke dalam tubuh serangga.

Awal kematian larva $H$. armigera di tandai dengan adanya perubahan tingkah laku larva $H$. armigera yang terjadi lima jam setelah aplikasi perlakuan. Perubahan tingkah laku larva $H$. armigera menunjukkan adanya menurunnya aktivitas seperti gerakan larva menjadi lamban, nafsu makan berkurang, larva terlihat lemah dan lama-kelamaan larva mati. Juliati et al. (2016) menyatakan bahwa semakin banyak ekstrak insektisida nabati yang menempel pada tubuh serangga atau pakannya, maka semakin banyak senyawasenyawa aktif yang bersifat toksik pada tubuh serangga. Banyaknya senyawa yang bersifat toksik tersebut akan mempengaruhi perilaku ulat dan dapat menurunkan aktivitas makan sehingga terjadi kematian.

Perubahan morfologi yang terjadi yaitu warna tubuh larva $H$. armigera yang semula berwarna kuning kecoklatan berubah menjadi coklat kehitaman pada 14 jam setelah aplikasi, selanjutnya perubahan terjadi 37 jam setelah aplikasi tubuh larva mengeluarkan cairan berwarna putih kekuningan kemudian mengeras dan selanjutnya berubah menjadi warna hitam (Gambar 1). 


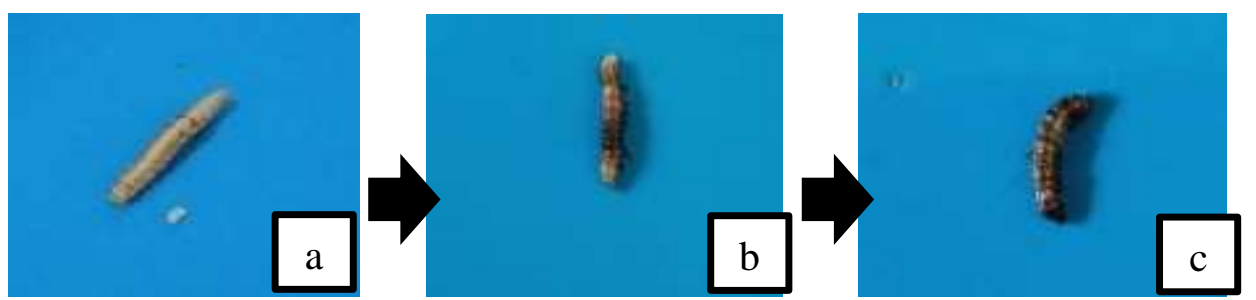

Gambar 1. Perubahan morfologi larva H. armigera dengan aplikasi ekstrak tepung daun bintaro (a) Larva $H$. armigera sehat (b) larva $H$. armigera mati 14 jam setelah aplikasi (c) larva H. armigera mati 37 jam setelah aplikasi (Dokumentasi Penelitian, 2019)

\subsection{Lethal Time $50\left(\mathrm{LT}_{50}\right)(\mathrm{jam})$}

Hasil pengamatan untuk mematikan larva $H$. armigera sebanyak $50 \%$ (lethal time 50) setelah dianalisis sidik ragam menunjukkan bahwa peningkatan beberapa konsentrasi ekstrak tepung daun bintaro memberikan pengaruh yang nyata terhadap waktu yang dibutuhkan ekstrak tepung daun bintaro untuk mematikan larva $H$. armigera sebanyak 50\%. Hasil uji lanjut beda nyata jujur (BNJ) pada taraf 5\% dapat dilihat pada Tabel 2.

Tabel 2. Rata-rata Lethal time 50 larva $H$. armigera dengan beberapa konsentrasi ekstrak tepung daun bintaro

Konsentrasi ekstrak tepung daun bintaro (g. $\mathrm{l}^{-1}$ air)

Lethal time 50 (jam)

$\begin{array}{cc}40 & 65,6 \mathrm{a} \\ 60 & 58,8 \mathrm{ab} \\ 80 & 57,4 \mathrm{ab} \\ 100 & 55,6 \mathrm{~b}\end{array}$

Angka-angka pada lajur yang diikuti oleh huruf kecil yang tidak sama berbeda nyata menurut uji BNJ pada taraf 5\%

Tabel 2 menunjukkan bahwa waktu yang dibutuhkan ekstrak tepung daun bintaro dalam mematikan $50 \%$ larva $H$. armigera pada konsentrasi $100 \quad$ g. $l^{-1}$ air lebih cepat dibandingkan dengan konsentrasi lain yakni sebesar 55,6 jam setelah aplikasi. Konsentrasi ekstrak tepung daun bintaro 100 g..$^{-1}$ air waktu yang dibutuhkan dalam mematikan $50 \%$ larva yaitu 55,6 jam berbeda nyata dengan konsentrasi ekstrak tepung daun bintaro $40 \mathrm{~g} . \mathrm{l}^{-}$ ${ }^{1}$ air waktu yang dibutuhkan untuk mematikan $50 \%$ larva yaitu 65,6 jam dan berbeda tidak nyata dengan konsentrasi 60 g. l $^{-1}$ air dan 80 g. $1^{-}$ 1 air dengan waktu yang dibutuhkan untuk mematikan $50 \%$ larva yaitu masing-masing 58,8 jam dan 57,4 jam. Hal ini juga terjadi pada waktu awal kematian dimana konsentrasi $100 \mathrm{~g}^{-1} \mathrm{l}^{-1}$ air (Tabel 1) menunjukkan waktu awal kematian larva $H$. armigera tercepat sehingga menunjukkan hasil yang sama dalam mematikan $50 \%$ larva $H$. armigera (Tabel 2). Hal ini diduga bahwa pemberian konsentrasi ekstrak tepung daun bintaro yang lebih tinggi dapat mempercepat waktu awal kematian dan waktu mematikan $50 \%$ larva $H$. armigera. Aminah (1995) menyatakan bahwa peningkatan konsentrasi berbanding lurus dengan peningkatan bahan racun, sehingga daya bunuh semakin tinggi.

Konsentrasi ekstrak tepung daun bintaro 80 g. $l^{-1}$ air dan 60 g. $1^{-1}$ air mampu menyebabkan kematian $50 \%$ larva $H$. armigera masing-masing pada waktu 57,4 jam dan 58,8 jam berbeda tidak nyata dengan konsentrasi lainnya. Hal ini diduga karena pada konsentrasi ekstrak tepung daun bintaro 80 g..$^{-1}$ air dan 60 g. $1^{-1}$ air senyawa flavonoid dan tanin yang terkandung dalam ekstrak tepung daun bintaro belum bekerja secara maksimal di dalam tubuh larva $H$. armigera. Syakir (2011) menyatakan bahwa kendala dalam penggunaan pestisida nabati adalah pestisida nabati tidak dapat bereaksi cepat dan relatif lambat dalam mematikan hama.

Konsentrasi ekstrak tepung daun bintaro 40 g. $1^{-1}$ air menunjukkan waktu yang dibutuhkan dalam mematikan $50 \% \mathrm{H}$. armigera paling rendah yaitu 65,6 jam dan berbeda tidak nyata dengan konsentrasi ekstrak tepung daun bintaro $60 \mathrm{~g} . \mathrm{l}^{-1}$ air dan $80 \mathrm{~g} . \mathrm{l}^{-1}$ air dengan waktu yang dibutuhkan dalam mematikan $50 \%$ larva $H$. armigera masingmasing yaitu 58,8 jam dan 57,4 jam namun berbeda nyata dengan konsentrasi ekstrak tepung daun bintaro 100 g..$^{-1}$ air mematikan 
$50 \%$ larva $H$. armigera 55,6 jam. Hal ini diduga bahwa pemberian konsentrasi ekstrak tepung daun bintaro yang lebih rendah senyawa flavonoid dan tanin yang terkandung dalam ekstrak tepung daun bintaro bekerja secara lambat. Rizal et al. (2010) menyatakan bahwa semakin rendah konsentrasi yang diberikan, maka semakin panjang waktu yang diperlukan untuk mematikan 50\% serangga dikarenakan semakin sedikit bahan aktif yang masuk ke dalam tubuh serangga.

Hasil penelitian Putri (2018) melaporkan bahwa pemberian konsentrasi ekstrak tepung daun bintaro dengan konsentrasi tertinggi 25 g. $1^{-1}$ air waktu yang dibutuhkan untuk mematikan 50\% larva $H$. armigera yaitu 67,2 jam, sedangkan hasil penelitian yang telah dilakukan dengan peningkatan konsentrasi ekstrak tepung daun bintaro yang lebih tinggi yaitu 40 g. $1^{-1}$ air mampu mematikan 50\% larva H. armigera lebih cepat yaitu $65,6 \mathrm{jam}$. Hal ini diduga semakin tinggi konsentrasi yang diberikan, maka kandungan senyawa aktif dari ekstrak tepung daun bintaro akan semakin tinggi pula sehingga berdampak pada waktu yang dibutuhkan untuk mematikan 50\% larva H. armigera menjadi lebih cepat. Hal ini sesuai dengan pendapat Natawigena (1993) bahwa proses kematian hama akan cepat dengan pertambahan konsentrasi ekstrak yang digunakan.

\subsection{Mortalitas Total (\%)}

Hasil pengamatan persentase mortalitas total larva $H$. armigera setelah dianalisis sidik ragam menunjukkan bahwa peningkatan beberapa konsentrasi ekstrak tepung daun bintaro memberikan pengaruh yang nyata terhadap persentase mortalitas total larva $H$. armigera. Hasil uji lanjut beda nyata jujur (BNJ) pada taraf 5\% dapat dilihat pada Tabel 3.

Tabel 3. Rata-rata mortalitas total larva $H$. armigera dengan beberapa konsentrasi ekstrak tepung daun bintaro (\%)

\begin{tabular}{cc}
\hline Konsentrasi ekstrak tepung daun bintaro $\left(\mathrm{g} . \mathrm{l}^{-1}\right.$ air) & Mortalitas total (\%) \\
\hline 40 & $70 \mathrm{~b}$ \\
60 & $72 \mathrm{~b}$ \\
80 & $82 \mathrm{ab}$ \\
100 & $90 \mathrm{a}$ \\
\hline
\end{tabular}

Angka-angka pada lajur yang diikuti oleh huruf kecil yang tidak sama berbeda nyata menurut uji BNJ pada taraf 5\% setelah ditransformasikan dengan $\operatorname{Arcsin}^{-1} \sqrt{y}$

Tabel 3 menunjukkan bahwa mortalitas total larva $H$. armigera tertinggi terdapat pada konsentrasi ekstrak tepung daun bintaro 100 g. $1^{-1}$ air yang mampu mematikan larva $H$. armigera sebesar $90 \%$ dan berbeda nyata dengan konsentrasi ekstrak tepung daun bintaro 40 g. $1^{-1}$ air dan 60 g. $1^{-1}$ air namun berbeda tidak nyata dengan konsentrasi ekstrak tepung daun bintaro 80 g..$^{-1}$ air. Hal ini juga berkaitan dengan waktu awal kematian dan $\mathrm{LT}_{50}$ larva $H$. armigera tercepat yaitu dengan waktu awal kematian 14 jam dan $\mathrm{LT}_{50}$ selama 55,6 jam. Hal ini diduga bahwa semakin tinggi konsentrasi yang digunakan maka semakin banyak senyawa aktif yang masuk ke dalam tubuh larva $H$. armigera sehingga menyebabkan mortalitas total larva $H$. armigera semakin besar. Pendapat ini sesuai dengan Sutoyo dan Wiriadmojo (1997) dalam Ningsih et al. (2017) menyatakan bahwa semakin tinggi konsentrasi maka jumlah racun semakin banyak yang mengenai kulit serangga sehingga meningkatkan efektifitas dan dapat menghambat pertumbuhan serta menyebabkan kematian serangga lebih banyak.

Konsentrasi ekstrak tepung daun bintaro $80 \mathrm{~g} .^{-1}$ air dengan mortalitas total sebesar $82 \%$ berbeda tidak nyata dengan konsentrasi lainnya. Hal ini diduga bahwa larva $H$. armigera masih mampu menyingkirkan senyawa aktif yang terkandung dalam ekstrak tepung daun bintaro sehingga pemberian konsentrasi ekstrak tepung daun bintaro 80 g. $1^{-}$ ${ }^{1}$ air memberikan pengaruh yang bebeda tidak nyata terhadap konsentrasi lainnya. Menurut Prijono (1999) yang menyatakan bahwa kepekaan suatu serangga terhadap senyawa bioaktif tertentu dapat disebabkan oleh sifat sistem penghalang masuknya senyawa tersebut ke dalam tubuh serangga misalnya ketebalan kutikula, ketahanan bagian sasaran atau kemampuan metabolik serangga yang dapat menguraikan dan menyingkirkan bahan racun dari tubuhnya. Namun konsentrasi ekstrak tepung daun bintaro $80 \mathrm{~g} . \mathrm{l}^{-1}$ air ini telah efektif dalam mengendalikan hama $H$. armigera. Hal ini sesuai dengan pernyataan Dadang dan 
Prijono (2008) yang menyatakan bahwa pestisida nabati dikatakan efektif apabila perlakuan tersebut dapat mengakibatkan kematian serangga uji melebihi $80 \%$.

Konsentrasi ekstrak tepung daun bintaro 60 g. $1^{-1}$ air dengan mortalitas total sebesar $72 \%$ berbeda tidak nyata dengan konsentrasi ekstrak tepung daun bintaro $40 \mathrm{~g} . \mathrm{l}^{-1}$ air dan $80 \mathrm{~g} . \mathrm{l}^{-1}$ air yaitu masing-masing $70 \%$ dan $82 \%$. Hal ini diduga bahwa larva $H$. armigera masih memberikan respon yang sama terhadap senyawa aktif yang terkandung dalam ekstrak tepung daun bintaro sehingga peningkatan konsentrasi yang diberikan tidak menimbulkan perbedaan yang nyata dalam hal mematikan larva $H$. armigera.

Berdasarkan hasil penelitian Putri (2018) menunjukkan bahwa pemberian ekstrak tepung daun bintaro dengan konsentrasi tertinggi 25 g. $l^{-1}$ air hanya mampu mematikan larva $H$. armigera dengan mortalitas total sebesar $52,5 \%$, sedangkan hasil penelitian yang telah dilakukan dengan konsentrasi yang lebih tinggi yaitu 40 g..$^{-1}$ air mampu mematikan larva $H$. armigera dengan mortalitas total yang lebih tinggi yaitu $70 \%$ begitu juga dengan peningkatan konsentrasi ekstrak tepung daun bintaro 60 g..$^{-1}$ air, 80 g..$^{-1}$ air, dan 100 g..$^{-1}$ air yaitu masing-masing $72 \%, 82 \%$ dan $90 \%$.

Kemampuan ekstrak tepung daun bintaro dalam mematikan larva $H$. armigera disebabkan karena daun bintaro mengandung senyawa flavonoid, tanin, saponin dan steroid yang memberikan efek terhadap mortalitas larva. Senyawa aktif yang terkandung dalam ekstrak tepung daun bintaro ini masuk ke dalam tubuh larva $H$. armigera sebagai racun perut dan racun kontak. Menurut Purwani et al (2017) bahwa senyawa aktif yang terkandung dalam ekstrak daun bintaro dapat menyebabkan gangguan aktifitas makan larva yang masuk ke dalam tubuh larva melalui lubang alami dan proses makan larva, senyawa aktif yang terkandung dalam ekstrak daun bintaro ini akan menganggu proses penyerapan nutrisi dan sekresi enzim pada tubuh larva sehingga proses pencernaan makanan akan terganggu dan larva akan kekurangan energi yang mengakibatkan larva mati.

Flavonoid merupakan senyawa pertahanan tumbuhan yang bersifat menghambat nafsu makan serangga yang juga dapat berperan sebagai racun pernafasan. Flavonoid masuk ke dalam tubuh larva $H$. armigera melalui alat pernafasan larva yang selanjutnya akan menggangu sistem pernafasan dan menyebabkan larva mati. Ismatullah (2014) menyatakan bahwa flavonoid masuk ke dalam tubuh larva melalui sistem pernafasan yang kemudian akan menimbulkan kerusakan pada syaraf serta sistem pernapasan dan mengakibatkan larva tidak bisa bernapas dan akhirnya mati.

Tanin yang juga terkandung dalam ekstrak tepung daun bintaro merupakan komponen yang berperan sebagai pertahanan tanaman terhadap serangga yaitu dengan cara menghalangi serangga dalam mencerna makanan. Tanin mengganggu serangga dalam mencerna makanan karena tanin akan mengikat protein dalam sistem pencernaan yang diperlukan serangga untuk pertumbuhan sehingga proses penyerapan protein dalam sistem pencernaan menjadi terganggu (Purwani et al., 2017). Chintihia (2015) menyatakan bahwa serangga yang memakan tumbuhan dengan kandungan tanin tinggi akan memperoleh sedikit makanan, akibatnya akan terjadi penurunan pertumbuhan. Respon serangga terhadap senyawa ini adalah menurunnya laju pertumbuhan dan gangguan nutrisi.

\section{KESIMPULAN DAN SARAN}

\section{Kesimpulan}

Pemberian ekstrak tepung daun bintaro dengan konsentrasi 80 g. $1^{-1}$ air merupakan konsentrasi yang efektif untuk mengendalikan hama $H$. armigera dimana dapat menyebabkan mortalitas total sebesar $82 \%$ dengan awal kematian 15,4 jam setelah aplikasi dan $\mathrm{LT}_{50}$ 57,4 jam setelah aplikasi.

\section{Saran}

Berdasarkan hasil penelitian yang telah dilakukan dengan uji beberapa konsentrasi ekstrak tepung daun bintaro (Cerbera manghas L.) terhadap hama penggerek tongkol jagung manis (Helicoverpa armigera Hubner) disarankan menggunakan konsentrasi 80 g. $\mathrm{l}^{-1}$ air karena dapat menyebabkan mortalitas total sebesar $82 \%$.

\section{UCAPAN TERIMA KASIH}

Kepada PLP Laboratorium Hama Tumbuhan Fakultas Pertanian Universitas Riau, Kampus Bina Widya km 12,5, Pekanbaru, yang telah membantu kelancaran pelaksanaan penelitian ini. 


\section{DAFTAR PUSTAKA}

Aminah, S. N. 1995. Evaluasi Tiga Jenis Tumbuhan sebagai Insektisida dan Repelant terhadap Nyamuk di Laboratorium. Tesis (Tidak dipublikasikan). Institute Pertanian Bogor. Bogor.

Chintihia, T. 2015. Efek larvasida ekstrak daun cengkeh (Syzygium aromaticum L.) terhadap Aedesa egypti. J Agromed Unila 2(4) : 510-515

Dadang dan D. Prijono. 2008. Insektisida Nabati : Prinsip, Pemanfaatan dan Pengembangan. Departemen Proteksi Tanaman. Bogor.

Direktorat Jenderal Tanaman Pangan. 1989. Penanganan Pestisida untuk Pertanian Tanaman Pangan. Direktorat Jenderal Tanaman Pangan Direktorat Perlindungan Tanaman Pangan. Jakarta.

Dewi A.Y.M. 2017. Uji Beberapa Konsentrasi Tepung Biji Pinang (Areca catechu L.) terhadap Mortalitas Larva Penggerek Tongkol Jagung Manis (Helicoverpa armigera Hubner). Skripsi (Tidak dipublikasikan). Universitas Riau. Pekanbaru.

Ismatullah, A. 2014. Uji Efektivitas Larvasida Ekstrak Daun Binahong (Anredera cordifolia (Ten) Steenis) terhadap Larva Aedes aegypti instar III. Skripsi (Tidak dipublikasikan). Fakultas Kedokteran Universitas Lampung. Lampung

Juliati, M. Mardiansyah dan T. Arlita. 2016. Uji beberapa konsentrasi ekstrak daun bintaro (Cerbera manghas L.) sebagai pestisida nabati untuk mengendalikan hama ulat jengkal (Plusia sp.) pada trembesi (Samanea saman (Jacq.) Merr.). Jom Faperta UR. 3(1): 3-5

Mulyana. 2002. Ekstraksi Senyawa Aktif Alkaloid, Kuinon dan Saponin dari Tumbuhan Kecubung sebagai Larvasida dan Insektisida terhadap Nyamuk Aedes aegepty. Skripsi (Tidak dipublikasikan). Institut Pertanian Bogor. Bogor.

Natawigena, H. 1993. Dasar-dasar Perlindungan Tanaman. Penerbit Triganda Karya. Bandung.

Ningsih, Y. D. Salbiah dan A. Sutikno. 2017. Uji beberapa konsentrasi tepung daun gamal (Gliricidia sepium Jacq) terhadap hama Sitophilus zeamais M. pada biji jagung di penyimpanan. JOM Faperta. $4(1): 1-15$
Prijono D. 1999. Prinsip-Prinsip Uji Hayati. Bahan Pelatihan Pengembangan dan Pemanfaatan Insektisida Alami. Pusat Pengendalian Hama Terpadu. Institut Pertanian Bogor. Bogor.

Purwani, K.I., S. Nurhatika, D. Ermavitalini, T.B. Saputro and D.S. Budiarti. 2017. Reducing the level of leaves damage of (Brassica rapa) caused by armyworm (Spodoptera litura F.) through liquid bioinsecticide formulation of bintaro (Cerbera odollam) leaves extract. Proceeding of International Biology Conference. 1-9

Putri, R.Y.R. 2018. Uji Beberapa Konsentrasi Ektrak Tepung Daun Bintaro (Cerbera manghas L) terhadap Mortalitas Larva Helicoverpa armigera Hubner (Lepidoptera : Nuctuidae) pada Jagung Manis. Skripsi (Tidak dipublikasikan). Universitas Riau. Pekanbaru.

Rizal, D., D. Mutiara, I. Lestari. 2010. Uji toksisitas akut serbuk kering daun sirsak (Annona muricata Linn.) terhadap kutu beras (Sitophilus oryzae L.). Sainmatika. 7(2) : 33-39.Sudarmo, S. 2009. Pestisida Nabati dan Pemanfaatannya. Kanisius. Yogyakarta.

Sarwono, B. Pikukuh, R. Sukarno, E. Korlina dan Jumadi. 2003. Serangan ulat penggerek tongkol Helicoverpa armigera pada beberapa galur jagung. Jurnal Agrosains. 5(2) : 28-32

Shahabuddin dan Pasaru F. 2009. Pengaruh efek penghambatan ekstrak daun widuri terhadap pertumbuhan larva Spodoptera exigua Hubn. (Lepidoptera: Nocudae) dengan menggunakan indeks pertumbuhan relatif. Jurnal Agroland, 16(2): $148-154$

Sholahuddin, A.H, W. Subchan and J. Prihatin. 2018. Toxicity of granules of bintaro leaf extract (Cerbera odollam Gaertn.) on armyworm (Spodoptera litura Fab.). Bioedukasi. 16(1) : 15-21

Syahputra, E. dan Endarto, O. 2012. Aktivitas insektisida ekstrak tumbuhan terhadap Diaphorina citri dan Toxoptera citricidus serta pengaruhnya terhadap tanaman dan predator. BionaturaiJurnal Ilmu-ilmu Hayati dan Fisik. 14(3) : 207-214

Syakir M. 2011. Status Penelitian Pestisida Nabati. Balai Penelitian dan 
Pengembangan Tanaman Perkebunan Bogor. Bogor

Wibowo, L. Indrayati dan Solikin. 2008. Uji beberapa ekstrak kasar buah pinang, akar tuba, patah tulang, dan daun mimba terhadap keong emas (Pomacea canalicukata) di rumah kaca. Jurnal HPT Tropika. 8(1) : 17-20

Yunita, J.E.A., N.H. Suprapti dan J.S. Hidayat. 2009. Ekstrak daun teklan (Eupatorium riparium) terhadap mortalitas dan perkembangan Aedes aegyptii. Bioma. 11(1): 11-17.

Zulaiha, S. Suprapto dan D. Apriyanto. 2012. Infestasi beberapa hama penting terhadap jagung hibrida pengembangan dari jagung lokal Bengkulu pada kondisi input rendah di dataran tinggi andisol. Naturalis Jurnal Penelitian Pengelolaan Sumberdaya Alam dan Lingkungan. 1(1) : $15-28$ 